\title{
The Diaries of Mary Seton Watts (1849-1938): A Record of Her Conjugal Creative Partnership with ‘England's Michelangelo', George Frederic Watts (1817-1904)
}

\section{Lucy Ella Rose}

To cite this article: Lucy Ella Rose (2017) The Diaries of Mary Seton Watts (1849-1938): A Record of Her Conjugal Creative Partnership with 'England's Michelangelo', George Frederic Watts (1817-1904), Life Writing, 14:2, 217-231, DOI: 10.1080/14484528.2017.1291248

To link to this article: https://doi.org/10.1080/14484528.2017.1291248

$$
\begin{aligned}
& \text { (c) } 2017 \text { The Author(s). Published by Informa } \\
& \text { UK Limited, trading as Taylor \& Francis } \\
& \text { Group }
\end{aligned}
$$
曲 Published online: 03 Apr 2017.

崩

Submit your article to this journal

Ull Article views: 197

Q View related articles $₫$

View Crossmark data ð 


\title{
The Diaries of Mary Seton Watts (1849-1938): A Record of Her Conjugal Creative Partnership with 'England's Michelangelo', George Frederic Watts (1817-1904)
}

\author{
Lucy Ella Rose \\ School of English and Languages, University of Surrey, Guildford, UK
}

\begin{abstract}
While much has been written about the famous Victorian artist George Frederic Watts (1817-1904), dubbed 'England's Michelangelo', the life and works of his wife Mary Seton Watts (1849-1938) are comparatively neglected. Mary was not only an artist and designer but also a writer and diarist, although her diaries have never before been studied. This article explores the Wattses' conjugal creative partnership through a reading of Mary's diaries covering their marital years (1886-1904), offering an unprecedented insight into their professional and personal relationship. It not only reveals their facilitating roles in each other's creative practices, but also the tensions and gender-role inversions in their partnership, challenging traditional perceptions of Mary as George's peripheral, submissive wife. Unlike her selfeffacing published biography of George Watts, Mary's private life writing reveals her role as a respected artistic equal, intellectual companion and even 'brutal taskmaster'. This article explores the Wattses' artistic collaborations, joint reading practice, and life/ death writing through a reading of Mary's long-forgotten diaries, which document her approach to marriage, gender, art and literature. It recovers her culturally-important life writing, traces the emergence of her artistic identity and feminist voice, and reclaims her as a remarkable diarist.
\end{abstract}

\section{KEYWORDS}

Mary Seton Watts; George Frederic Watts; diary; creative partnership; marriage; art

\section{Introduction: Mary's diaries and women's suffrage}

Mary Seton Watts (née Fraser Tytler, 1849-1938) was a pioneering professional woman artist and designer for Liberty of London as well as an illustrator, writer and diarist. Yet she is little known, having been long-eclipsed by the dominant critical focus on her husband George Frederic Watts (1817-1904), hailed 'England's Michelangelo' (Blunt). Mary's ${ }^{1}$ authorial role is even less recognised than her artistic role, and her life writing has never before been studied. In addition to publishing a guide to her symbolic decoration, The Word in the Pattern, and her husband's biography, The Annals of An Artist's Life, Mary kept private notebooks, journals and diaries (Figure 1). 


\section{Wednesday, August 26.}

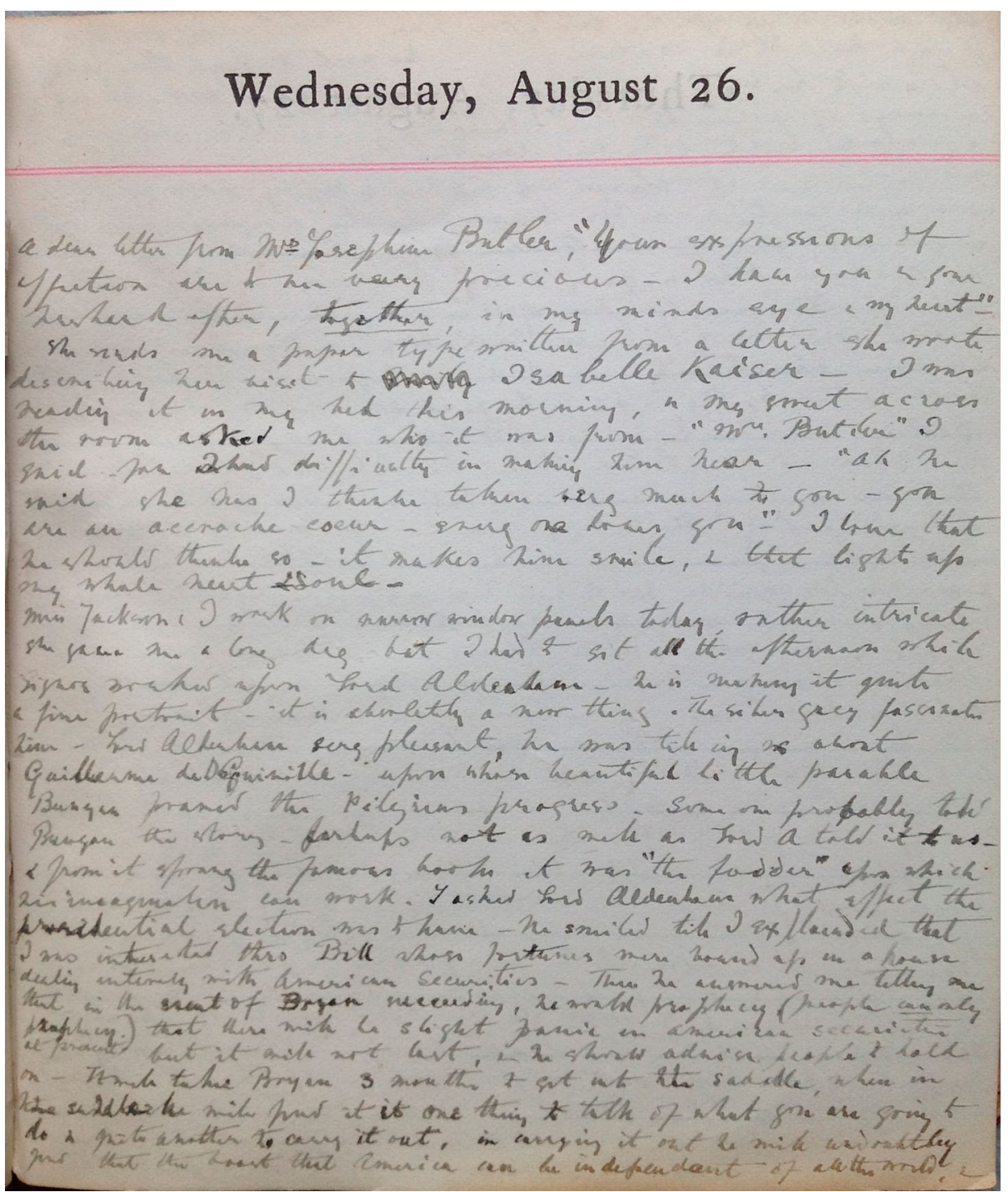

Figure 1. Mary Watts's manuscript diary. Watts Gallery.

Mary's eight daily-written manuscript diaries_-generally updated early in the morning, sometimes in bed or at a table on the landing-cover the Wattses' marital years and just after George's death (1886-1908), bridging Victorian and Edwardian periods. They thus record a critical stage in Mary's personal life and career during a time of significant socio-political and cultural change when (Mary writes in her diary) 'woman [was] beginning to take her place' (4 April 1893).

Mary affectionately named each of her diaries 'Fatima', as though they were living female confidants rather than domestic household records. This is intriguing in light of the painting Fatima (1862) by the Wattses' close friend Edward Burne-Jones, depicting a woman unlocking her husband's secret closet with a key. ${ }^{2}$ Mary's diaries offer a unique and unprecedented insight into her professional as well as personal relationship 
with her husband, revealing their marital dynamic and Mary's own character to be far more multifaceted than critics have previously perceived. Challenging traditional perceptions of Mary as George's amanuensis, 'acolyte and servant' (Bills 16) who 'worshipped him blindly' (Blunt xviii), this article reveals Mary's complex role and creative agency as devoted wife, creative partner and self-proclaimed 'brutal task master' (27 February 1893).

The non-gendered yet traditionally male account of a professional artist's career punctuates Mary's ostensibly conventional wifely narrative. Combining word and sketch, her diaries can be seen as sites of artistic inception, and can be read together as a fragmented Victorian-Edwardian künstlerroman: she logs her first experiments with gesso and photography in 1887, and the creation of her ceiling panels and reading alcove at her marital home in 1891. Domestic and artistic, familial and professional, highly-gendered and non-gendered interests and narratives are inextricably linked in Mary's diaries, combining two ostensibly 'contradictory autobiographical modes' (Peterson 32). Mary's diary writing presents an atypical example of a Victorian woman whose sense of self is defined in relation to her familial status (as wife) as well as to her occupational status (as artist); Mary demonstrated how these two apparently mutually-exclusive identities could successfully coexist. Her diaries provided her with life writing opportunities and forms of self-representation, and are crucial to an understanding of both her professional self-development and her female lived experience.

Mary's diaries may be compared with those of her predecessors Dorothy Wordsworth and Edith Simcox in the way they are 'characterised by their tendency to consistently foreground another person' (Millim 982). Yet unlike Edith Simcox's “'tribute”-diary to George Eliot' and Dorothy Wordsworth's diary which 'left out the self (Millim 982) in its focus on William Wordsworth, as well as Mary's own self-effacing three-volume biography or rather hagiography of George, Mary's diaries reveal her self-perception as a serious professional artist 'working like a tiger' (10 February 1891) and record her largely unrecognised influence on her husband's artwork. Although Dorothy Wordsworth's journals reveal her creative partnership with William, she never presents herself explicitly as an influence. While Mary mentions or quotes George in almost every entry, some record her defiance rather than deference, and several critique his artwork; she confidently asserts herself and expresses aesthetic views distinct from his, documenting the emergence of a strong, arguably feminist voice. This article reveals both the joys and tensions of togetherness, exploring moments of power-play and gender-role inversion in the Wattses' partnership, and thus showing how Mary's diaries can be seen as sites of struggle rather than submission. The reading of Mary's diaries as a record of her anti-patriarchal conjugal creative partnership offers a contribution to the feminist life writing and auto/ biography scholarship that has attempted to recover neglected nineteenth-century women writers and re-read forgotten women's texts.

Mary was an ardent suffragist, and states in the published biography of her husband that they were 'agreed [...] that feminine influence in politics would have a good effect, especially upon social questions' (Annals II 146). However, this is a brief, sanitised public statement compared to her passionate diary entries which reveal the strength and extent of her-if not her husband's-feminist feeling. In 1891, Mary attended a rousing lecture by British philanthropist and women's rights campaigner Lady (Isabel) Henry Somerset, whose 'great work', 'strong nature' and oratory she greatly admired. 
Such speeches may have influenced Mary's increasingly confident voice both inside and outside the studio, as well as her feminist views. Inspired, she writes in her diary,

I felt very proud of 'woman', for her clear round voice, her fluent earnest speech, left all the male speakers far behind. Two Members of Parliament were amongst them-She touched on woman's influence in legislation, \& its moral action, [...] and how they will not stand having immoral men making laws for them as they do [...] I heard 3 charming women speak on that platform [...] \& more womanly, or charming, the impression of all three could not be-they spoke to the purpose, \& saw the truth clear \& directly. [...] How I wished that my dear one could have been there \& could have heard. (1 May 1891)

Mary's reference to her husband implies the Wattses' shared sympathy for women's causes, yet while George painted portraits of Isabel and her family, his absence from the lecture signifies his lack of active support. In an interview of 1895, George admits, 'I have only strength enough for my work, and for nothing besides; therefore, I have determinedly kept aloof from politics' (Friederichs 78)-beyond his studio walls. Mary's pride in 'woman' as a strong speaking subject with intellectual and social presence and power, and her description of the speakers' 'womanly' impression, implies her acknowledgement of sexual difference, but one that involves a perception and celebration of women's capability rather than inadequacy. She later writes that she admired the 'great liberality of the non-conformist mind' and people who desired 'to know everything that is good \& great \& large-dissatisfied with all that is merely conventional orthodox \& narrow' (28 June, 30 May 1893), and she is left 'trembling' with excitement at the prospect of 'a free intercourse between men \& women [...] boys \& girls educated together at the same schools' (4 April 1893) during a discussion with writer and women's suffrage supporter George Meredith.

While, on the whole, Mary was liberal and progressive rather than radical and avantgarde, towards the turn of the century she may have shared the growing suffrage spirit of rebellion in the face of women's sustained political oppression. She writes, 'when I think of [that social evil and the abominable injustice of prostitution] I feel as if I must get up \& go -leave [George] everything!' (30 January 1893), and when George is gravely ill she writes, 'what is to become of my life when [he dies] - to help others is what I want to see before me' (20 May 1891). Mary records her frail husband's heavy dependency on her in his illness and old age, and how political violence distressed him; he was too nervous and sensitive to directly or actively support women's suffrage. ${ }^{3}$ Yet surely it is no coincidence that Mary's involvement in suffrage activity increased significantly after George's death. She became President of the Godalming and District National Union of Women's Suffrage Society (from 1909), and held a large newspaper-worthy suffrage meeting in 1913, where she gave a presidential address on the place and potential of women. ${ }^{4}$ While the Wattses were united as artists, symbolists, philanthropists and suffragists, the large agegap between the couple partly contributed to the differences in their views, voices and interests, and this intergenerational divide-highlighting shifts in attitude across the decades of the nineteenth century-is perceptible in her diary entries explored here.

\section{Working together: artistic collaborations}

The conjugal creative partnership of the 1870s and 1880s-as exemplified by the Wattses and their contemporaries William and Marie Spartali Stillman (married 1871), and William and Evelyn De Morgan (married 1887) - was a revolutionary approach to 
marital politics that shifted and subverted the traditional (im)balance in power relations between the sexes. Although joint ventures were not uncommon in the mid- to late-nineteenth century, for many Victorian women artists, marriage was the ultimate impediment to their professional creative practices. ${ }^{5}$ Mary's relatively late entry into matrimony at almost 37 (when the average age of marriage for middle-class women was 25) is a good example of the 'strategy adopted by many women in the 1860s and 70s [and 80s] who wanted to pursue the increasing opportunities opening up to them in employment, education and politics' (Unwin 240).

Not long after their marriage, the Wattses moved into their Surrey studio-house (built 1890-1891), which they called 'Limnerslease'- 'limner' being Latin for 'artist' and 'leasen' being the Old English word meaning 'to glean', their hope being that there were golden years of creativity to be gleaned from this home. The Wattses worked together and alongside each other in opposite studios in this home and its grounds. Mary writes in her 1887 diary-which can be read as a 'Professional/Intellectual' Victorian honeymoon diary (Michie 44-45)_'A lovely day, life seems like a dream [...] My loved one working [...] \& I with my easel below him in the garden designing' (30 July). Such entries pervade her diaries, and reveal the great contentment they found in a domestic space and routine that prioritised and facilitated artistic productivity. On one occasion, George 'take[s] up the little pen' and writes in Mary's 1887 diary on the subject of the 'harmony' of 'the human form' (9 January). The presence of both Mary's and George's handwriting on the (typically private) page-a unique example of the Wattses' double diary-writing-suggests the intimacy between the two. This, as well as the equality and reciprocity of their relationship, seems symbolised by the plaster cast of the Wattses' clasped left hands (1886), which they had made on their wedding day as a token of their partnership; Mary refers to it in her diary as the 'dear blessed symbol of our double yet one life' (18 August 1891, Figure 2).

There are many parallels and points of dialogue between the works of the Wattses who shared an allegorical iconographic vocabulary despite (predominantly) working in different media: they embodied a marriage of Arts and Crafts. The symbiotic relationship between their works is exemplified by Mary's symbolic recreation of George's three paintings Love and Life (c.1884-85), Love and Death (1885-87) and Love Triumphant (189398 ) in terracotta panels on a studio fireplace at Limnerslease. These works not only stand

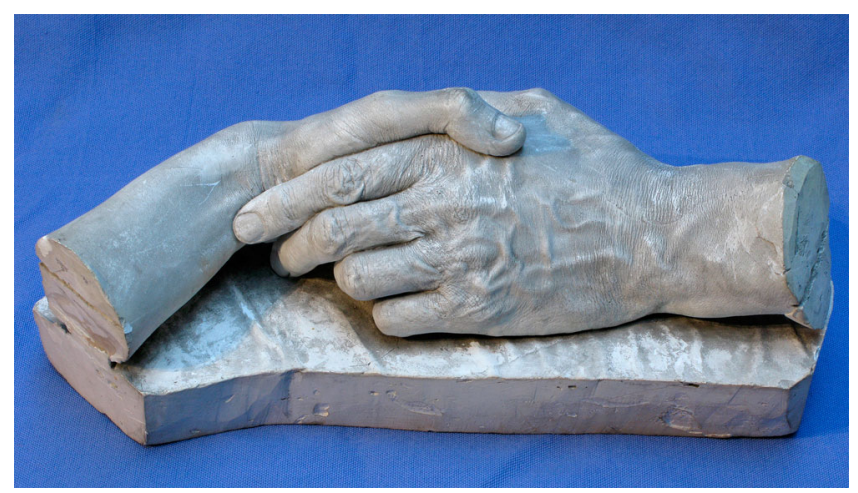

Figure 2. Plaster Cast of the Left Hands of Mary and George Watts, 1886. Watts Gallery. 
testimony to Mary's 'eclectic expression of Wattsian themes' (Gould 43) but also show her ability to transform art into craft, in stylised Art Nouveau and Celtic-style reinterpretations and adaptations of George's works. Similarly, Mary's Aldourie Triptych (18861903) recreates in relief three of George's compositions-The Messenger (1884-5), Love and Death (1885-7), and Death Crowning Innocence (1886-7) - which she modelled in clay and had cast in bronze for the entrance to her family cemetery in Scotland. Pattern for Mary, like paint for George, was a powerful discourse through which to communicate complex ideas about spirituality and universality as well as gender. Mary was no slavish copyist to her husband and did not simply imitate or replicate his works. Rather, she translated them into designs and symbolic terracotta decoration through which she not only expressed their shared ideas and ideals, but also developed her own distinctive voice.

That George highly valued Mary's opinion as a creative partner is conveyed by her diary of 1893, in which she records how he frequently requested her opinion, and how she was not afraid to speak her mind:

'Are you there' he calls up to my studio sometimes, $\&$ then he asks me to come $\&$ look at something he has done-Once, today, it was to see the [painting of the] little boy 'Promises'. What do you think of it? I said 'You have made the wings too real, \& have lost the dignity of the work-It is more sweet but less noble'-I dare to say what I think, I must! as he is too much in earnest not to wish me to do so-he has lost colour and quality in the wings and the picture is much damaged by it [...] An hour afterwards, \& he had much restored the quality. (16 January 1893)

George earnestly asks Mary for advice and hastily amends his painting Promises (1892-93) to meet her approval in an inversion and subversion of the male tutor/female student dynamic typical of the earlier nineteenth century. This passage speaks volumes about his perception of her as an artist of equal if not superior vision, as well as her confidence to express aesthetic ideas that conflicted with her husband's. Indeed, this entry records Mary asserting her own voice through (a traditionally male) artistic discourse-the sophistication, conviction and detail of which reflects her formal art training at the mixed-sex Slade School of Fine Art. Her exclamation and underlining of the word 'dare' suggest her excitement and pride in recording her transgression of traditional femininity and her active role in her husband's artistic process. Such entries challenge the longstanding perception of Mary: 'in awe of [George], overwhelmed by his reputation [...] as devoted and admiring as ever [...] in her subservient role' (Bills 14-15).

Mary's diaries reveal not only the Wattses' creative partnership but also the power-play at work within it. Another, more radical, gender-role inversion and subversion of patriarchal power relations occurs in the episode recorded in Mary's diary when she assumes the role of 'brutal task master' who expects George to meet her high aesthetic expectations:

He calls me in to look at his work [...] he has got the sky \& foreground now to his satisfaction \& mine, but I miss and still insist on his trying for the spark[1]ing [...] clear cut iridescent character of the icy peaks, once got but lost long ago at Brighton-'Now you've depressed me' he says, \& I feel a brutal task master-but I tell him he [showed] it to me once so I can't be satisfied with less. (27 February 1893)

Mary's interesting use of the word 'master' as a self-description (if somewhat tongue-incheek) suggests her awareness that she has, if only temporarily, assumed the dominant, powerful, traditionally male role of teacher in their relationship. The role-reversal is 
ironic given that many young women artists-including Mary herself in her early days of portrait painting-looked to the famous George Watts as master, referring to him as 'Signor', and were grateful to follow his teaching. Yet this dynamic was evidently not representative of their later conjugal creative partnership. Mary's diaries reveal her to be the driving force behind the creation of some of George's famous artworks (perhaps more than she records) which were only finished when they were to her satisfaction. She encouraged him to capture something of her creative vision as well as to fulfil his own artistic potential, which resulted-among other works-in George's visionary alpine landscape: what Mary refers to as the 'Ice Mountains' is possibly Sunset on the Alps (1888-94). Such paintings can be seen for the first time as collaborations of his skill and her vision.

However, Mary's diaries reveal that her strong-mindedness was not always appreciated by her husband, and this further complicates any straightforward view of their relationship. While it is not unusual for a married couple to experience the tensions of togetherness, George's criticisms of Mary's character and work approach the very patriarchal discourse that he generally eschews, voicing the deeply-ingrained patriarchal principles of his time. When the couple had not yet been married a year, Mary records in her diary,

My loved one said to me today that I did not quite help him as I ought, to be better \& more kind in spirit-'How could I', I said 'unless I were to become quite an angel!' \& 'then wouldn't you want a little devil sometimes to play with[?]'-He tells me [he] thinks he could play with angels, \& not find them monotonous-He says to me 'Charity thinketh no evil'. I say 'Yes, but Charity's wife does'- (9 August 1887)

George criticises Mary's wilfulness or rather strong-spiritedness, tells her how she 'ought' to behave and voices an explicit desire for her subservience. Yet she does not silently acquiesce in self-criticism or shame, but rather contests his authority and even mocks him with her witty retorts; she meets his moralising comments with subversive humour. Her very record of this rebellious episode marks an unapologetic enjoyment in playing the transgressive role of the wicked 'little devil'-the antithesis of the angelic role she was expected to play as the wife of a great artist. While Mary has been perceived as 'the archetypal Victorian woman, the "angel in the home"' in that she "fulfilled the duties of a Victorian wife, caring for her husband' (Unwin 246), her diaries show that she does not fit Virginia Woolf's description of the self-abnegating 'Angel in the House' who 'never had a mind or a wish of her own, but preferred to sympathise always with the minds and wishes of others' (Woolf 237). Mary's record of her response, in which she directly quotes herself, suggests her pride in her secret rebellious spirit. Indeed, the 'life-writing potential of the diary' has been 'identified as a site for specifically female rebellion' and resistance; within its private pages a woman could 'challenge patriarchy in an attempt to recover her self-worth' (Delafield 16, 18).

Though Mary generally displays humour and resilience in such instances, George's disparaging and demeaning remarks sometimes adversely affect her. When Mary is inspired to draw her sister-in-law 'sitting by the fire, behind her the low red sun-lighted up her hair, with a coppery sort of [aureole]', which reminds her of an 'early Millais', and excitedly calls George 'to come \& see it', his disapproval leaves her deflated:

I tried to make a sketch-alas, I have no powers-when it was fairly finished, Signor looked at it coldly \& said the face should have been darker than the red wall behind, \& I tried to alter it with the usual result of spoiling it. I am not strong enough to be independent in my work, \& 
when I try to lean on him I fail entirely. Of course he sees things quite differently from me [...] (4 January 1893)

George supported and fostered Mary's creativity but also fuelled her insecurities about her artistic ability-perhaps out of a tactlessness, sense of rivalry, or keenness to reinstate his authority-convincing her of her inadequacy and failure. This highlights an important contradiction in the behaviour of older Victorian male artists towards younger women artists: many encouraged women to make artistic contributions and yet forced them into a role of dependence; Jan Marsh notes that even 'the kindest of men expected deference and obedience from his spouse and this was assumed to be the natural order of things' (qtd. in Peeters 25). Yet the Wattses' creative partnership necessarily entailed criticism as well as encouragement of each other's work, and some of Mary's reviews of George's work are equally 'cold'. She says she suffers 'the sorrows of the artist's wife' when George overworks Walter Crane's picture, turning it from an 'entrancing [...] work of genius' to 'nothing more than [an] ordinary portrait'; though George carries out her suggested alterations to the eyes and chin, she feels 'he will never recapture what he once had' (6 October 1891).

Mary's later 1896 diary reveals her rejection of patriarchal notions of femininity, as well as her husband's tacit approval of her progressiveness. In one entry describing her interaction with a male sculptor who visited the Wattses' home to have his portrait painted, Mary writes,

as I sat \& talked to [Sir Alfred Gilbert], I perceived more crankiness developing-women must not bicycle, girls should be kept in glass cases, \& he harped unpleasantly to me on the subject of the physical difference between men \& women. (29 September). ${ }^{6}$

Ten days later, Mary writes, 'A lovely morning [... I] walked out with the dear beloved, stepping along so lightly to look at a Bicycle I thought would do for us' (8 October). Less than a month later she had bought a bike and was determined to ride it, to her own and her husband's delight: 'My love very happy this morning because I had my 1st turn on my bicycle [...] I feel sure it will give me new power' (3 November).

Indeed, the bicycle is widely perceived to have endowed Victorian women with new freedom and independence; the inclusion of women cyclists in suffrage campaign activities (including the 1913 Suffragist Pilgrimage in which Mary participated) is well-documented, and it has even been suggested that 'cycling brought the sexes together on equal terms more completely than any previous [...] pastime' (Rubinstein 68). Mary's 1896 diary was written during the cycling craze, and in 1898 she records her enjoyment in bicycling publicly around the village with the Wattses' ward Lily and alongside male relatives. She thus defied restrictive feminine norms and what she recognised as outdated patriarchal notions of sexual difference that enforced female passivity, captivity and subordination. It is clear that her swift acquisition of, and determination to ride, a bike-which she describes with obvious pleasure-was a conscious act of protest rather than a merely practical purchase. George's presence at, if not participation in, its purchase and test-drive suggests he shared Mary's progressive views rather than those of his male sitter. This is a prime example of how personal and socio-political matters meet in Mary's autobiographical writing. 


\section{Writing about reading together: in life and death}

George's lifelong passion for literature was fuelled by his marriage to Mary, who was his intellectual equal, creative companion, and reading partner. In her unpublished diaries, Mary documents and discusses their readings in the 'niche' (1894-95, Figure 3): the couple's private reading alcove created and painstakingly decorated by her in painted gesso.

Far from being the strictly secret, private space to which Victorian women readers were more typically relegated, the 'niche' was a domesticated space at the heart of the Wattses' Arts and Crafts home, situated beside the hearth in the sitting room at Limnerslease. Here they spent almost every evening alone together once visitors had left. Mary wrote in her Annals that this alcove 'served a double purpose, for, as [George] was slightly deaf, the niche concentrated sound, and he heard better there, and so it became his favourite corner, and he chose to spend his evenings lying there, listening to [her] reading' (II: 86).

The 'niche' represented an alternative to, and even a radical departure from, the more conventional desk and the official, privileged reading space of the paternal library, study or office that excluded women. The Wattses' habitual position of recline in the 'niche' is also subversive in being more horizontal, 'free, relaxed [and] unregulated' than vertical, 'rigid, professional [and] ordered' (Lee 47). Mary's 'niche' can be seen as a female appropriation or (sub)version of the paternal library, where she educated herself under the guise of fulfilling her wifely duties by reading aloud to her husband. She thus successfully reconciled the 'conflict for women between domestic duties and reading time' (Lee 50), transforming a space of limitation (the hearth; the living room; the home) which traditionally signified

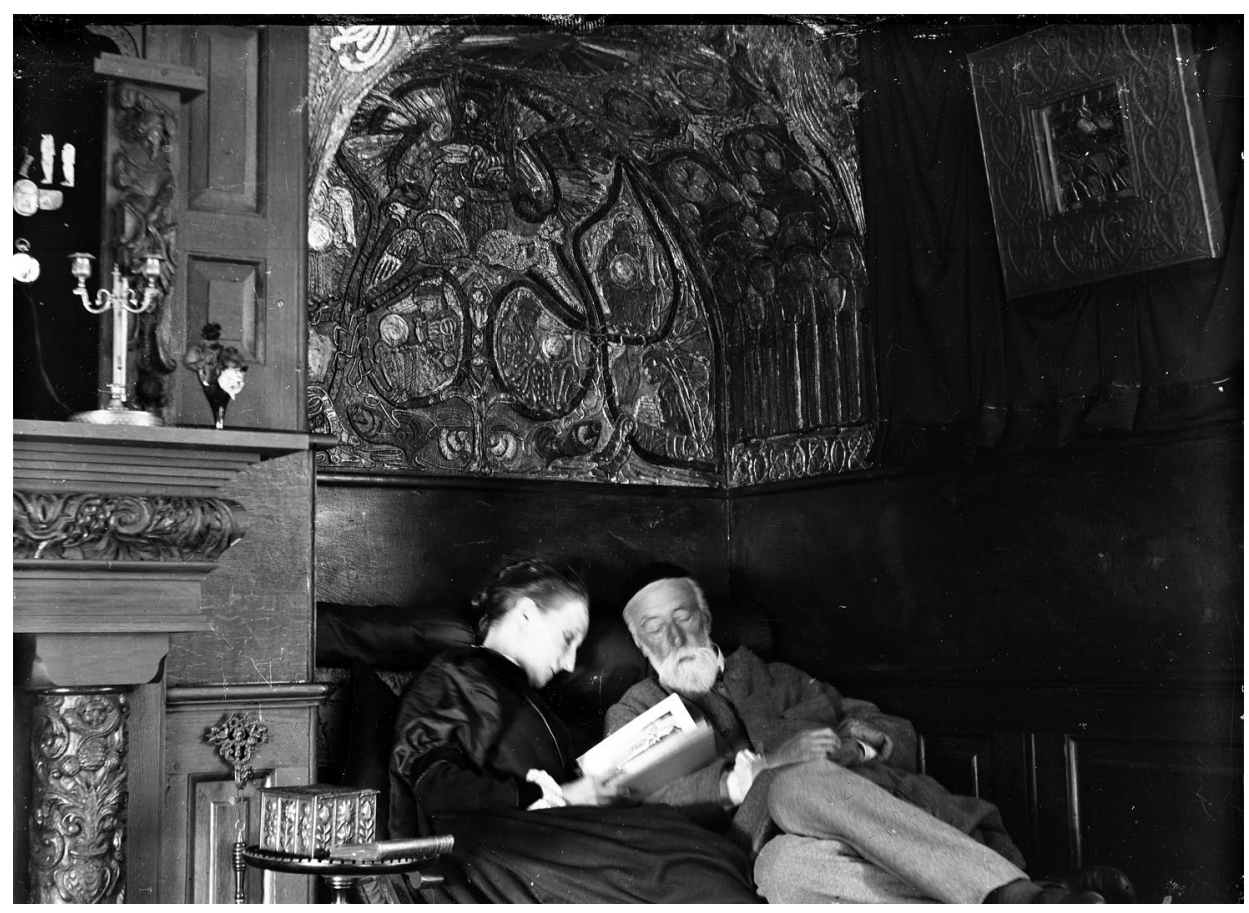

Figure 3. Mary and George Watts reading in the niche at Limnerslease, glass plate negative, c.1894-95. Watts Gallery. 
domestic captivity into one of greater liberty and gender equality. Mary describes the 'delicious hours' and many a 'happy evening' spent in the 'niche' with her husband, explicitly inscribing her pleasure, and celebrates a mind-expanding shared reading experience: 'Tonight in the happy niche, we read the oldest books in the world [...] "I feel as if a new room had been opened in my mind" I said [to George] afterwards' (7 January 1893).

Mary finished the 'niche' in time to present it to George as a birthday gift in 1893, which he described in 1895 as 'the first page of a beautiful book' (qtd. in Gould 32). Indeed, it was carefully designed to represent the Wattses' readings in this unique space: Mary writes,

[George] asked me what I was designing for the niche-I said I want it to be descriptive of the time we pass there-the things we think of chiefly-therefore I am trying to make my patterns express the whole range. Flowers trees birds beasts and man in his double nature spirit and flesh — sun stars moon-angels—and a light beyond [...] but that is not all-papyrus comes in for books, poppies for rest-\& then I am trying to get in painting, art, science, religion, history, fiction-he laughed 'Oh, you are greedy' he said- (1 February 1893)

Her symbols offer an exclusive insight into the impressive breadth of textual subjects and literary genres that inspired Mary's designs and George's paintings, and into the Wattses' private life and library. Mary's diaries record their readings in the 'niche' and subsequent discussions about the works of their famous literary predecessors and contemporaries, including Dante Gabriel Rossetti, Robert Browning, William Morris, George Meredith and Alfred Tennyson, whose faces feature in George's portrait collection the 'Hall of Fame'. At times, Mary's diary entries appear like a reading log, recording the Wattses' readings of novels, poems, articles, bibles and auto/biographies: one entry reads, 'In our evening we begin Mrs. Josephine Butlers [sic] life-[Personal Reminiscences of a Great Crusade, 1896] - a wonderful Joan of Arc!' (20 October 1896). The Wattses' progressive socio-political views-especially on the place and treatment of women-not only informed and fuelled, but were also shaped by, their readings.

Mary's diaries reveal the Wattses' shared interest in influential women writers. Mary records in her Annals that Jane Austen's novels were among the books George 'turned to most often when tired or unwell' (I 15), and she elaborates in her 1887 diary:

My dear one not well [...] I found [Austen's] Pride \& Prejudice [1813] \& began to read it to him. No novelist delights him more-it is so finished \& so complete, so without effort-just the right words used with reticence \& such graphic power [...] His love of it is delicious-like a child who likes the story over again [...] he corrected me if I missed a word- (20 April)

She also records how they were deeply moved by Elizabeth Gaskell's novel Cranford (1853), and particularly by the narrative of Miss Matilda 'Matty' Jenkyns, whose feelings for her former suitor are renewed when they are reacquainted, only for him to die shortly afterwards:

Our evening spent reading Cranford-it belongs to the same class as Miss Austen, but the pathetic is too much there for Signor-I read 'Miss Mattys' love story, \& said 'how lovely,' but had no answer, so I kissed my dear ones [sic] eyes \& found why he could not answer. He held my cheek to his, \& really cried for the poor tender little suffering heart, though only living in a book. (20 November)

That George is moved more than Mary-to tears-reveals his deep sympathy with female figures as well as a surprising sensitivity behind his patriarchal public image. Though Mary notes that the characters are 'only living in a book', Virginia Woolf remarks in her diary, 
'the truth is these little scenes [in books] embroil one, just as in life' (24 August 1933). Indeed, the tragic love story may have caused George (much older than Mary and in poor health) to reflect on his own mortality, and his and Mary's inevitable parting; their reading about the breaking of a union in a work of fiction strengthened their own in a tender private moment.

Given that reading together was so important to Mary and George, and their evenings in the 'niche' were among their happiest times at Limnerslease, it is fitting and poignant that George begs Mary to read to him in his last living moments. Her diary of 1904 records his death (aged 87) at their London home 'Little Holland House' - the full details of which are omitted from her Annals. It thus offers an unprecedented insight into the Wattses' final moments together. She writes,

I had not been there many minutes when quite strongly he called 'Mary Mary Mary come to me'-I sprung up \& was quickly holding his beloved hand once more-I had my bed (now nearly a month away from his side) pushed up once more \& lay beside him $-\&$ when he slept I slept my last sleep at his side. [... He said] suddenly to me 'Read to me'-I had no bookbut said the verses of the opening of [Alfred Tennyson's elegy] In Memoriam-'Strong Son of God Immortal Love' I could not remember them all-but he must have heard \& liked it for he said 'Say it again' [...] 'Why, why don't they come?' he cried after-meaning the great messenger he had so implored to come a few days before-The End. (30 June-1 July)

Mary's diaries also record the Wattses' earlier, light-hearted discussions about death:

We came to talk of death somehow—-the losing hold of all material things [...] 'Ah, but sweet' I said 'you will save with you a paintbrush when you get to the new life'-'That I am sure I shall' he said laughing. (20 February 1893)

Yet the moment of George's death is a very solemn and self-conscious occasion. This is suggested not only by Mary's readiness to recite the famous elegy by Tennyson (their close friend and poet laureate) but also her use of the narrative convention 'The End' to mark the conclusion of her diary entry and simultaneously their life together-though not her diary-keeping or artistic practice. Not long after George's death, Mary documents how she designed and modelled the 'flower from the crannied wall' (13 October 1904) for the hand of George's colossal Alfred Lord Tennyson memorial statue (c.1899, Figure 4); this collaboration was hailed a national art treasure and now stands outside Lincoln Cathedral. Given the cultural and literary fascination with famous figures' last words, Mary's life writing recording the death of 'England's Michelangelo' is of great cultural importance.

\section{Conclusion: the publication of Mary's diaries}

Acutely aware of her husband's reputation and legacy, as well as her own by association, Mary may have written her diaries with an awareness that they might one day be read and published. Indeed, revealing her own interest in life writing in her diaries, she mentions Marie Bashkirtseff: The Journal of a Young Artist 1860-1884 (published 1887, translated into English in 1889); Margaret Oliphant's Memoir of the Life of Laurence Oliphant and of Alice Oliphant his Wife (1891); and Mrs Sutherland Orr's Life and Letters of Robert Browning (1897). She compares her life writing to that of her female contemporaries: 'Reading [Georgiana Burne-Jones'] life-I envy her all the precise \& clean history she has of her beloved - of mine I can but garner here $\&$ there facts out a mist!' (30 December 


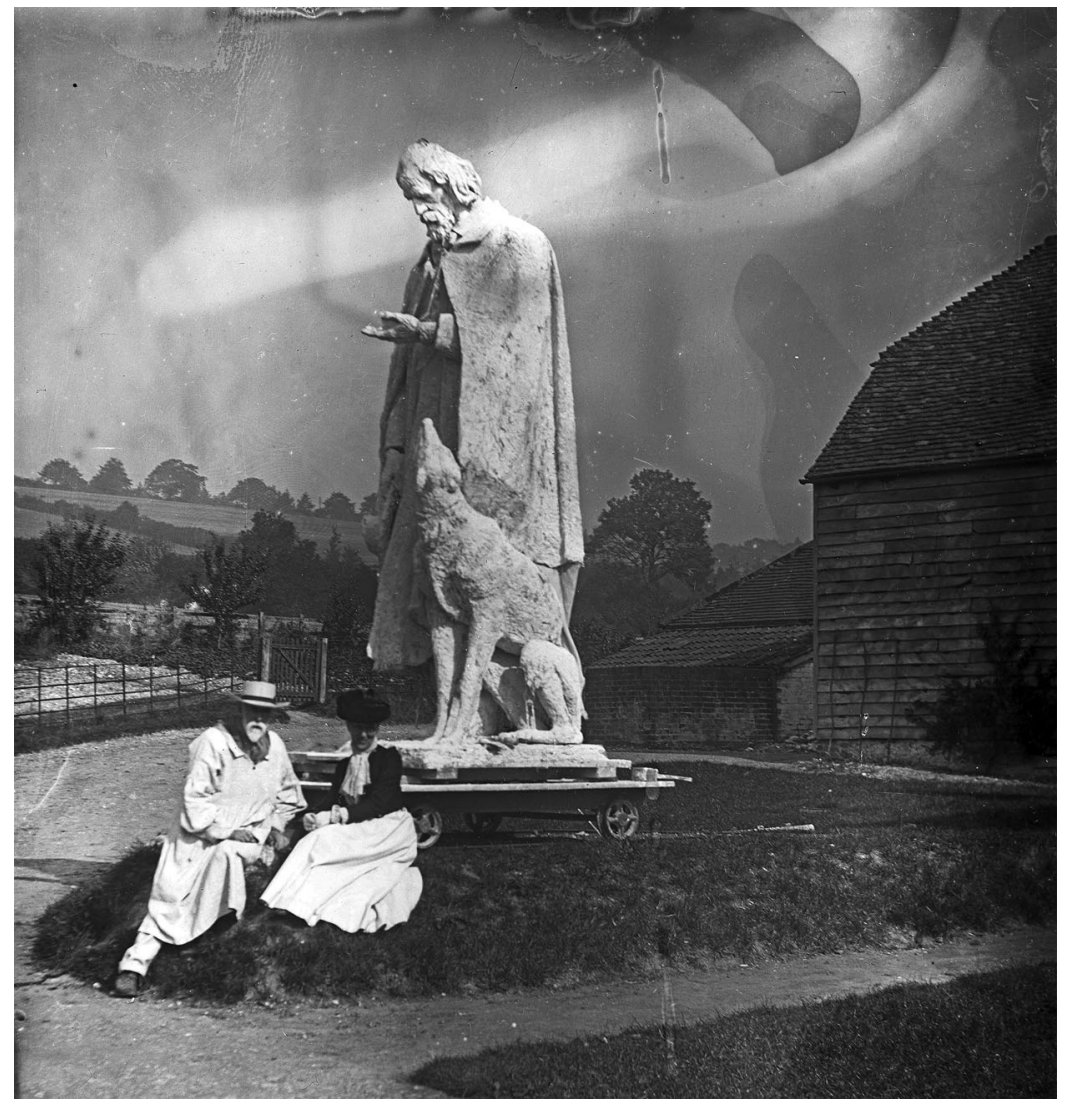

Figure 4. Mary and George Watts sitting outside the Barn Studio by the Tennyson Statue, glass plate negative, c.1899. Watts Gallery.

1904). She would also have been aware of published diaries by her female predecessors such as Frances Burney and Emily Shore. Consciously or unconsciously, her readings must have influenced her writing, and her ambition to publish her diaries is suggested in the very first one: 'We [she and George] took up Fatima \& read some of the notes \& hope to work them out \& put them into better form one day' (3 April 1887).

A consideration of the possibility that Mary's diary writing is a self-consciously performed narrative in which she assumes roles or author-characters for a future audience allows it to be read as a canny self-fashioning and even self-promoting strategy through which she aims to (posthumously) challenge public perceptions of her as a submissive angel-wife, as well as wider patriarchal concepts of femininity. There certainly seems to be a performative aspect to her anecdotes, especially in the use of quoted dialogue in the recreation of scenes. Popular critical arguments that 'keeping a diary must entail an imagined reader, whether actual, eventual, or altogether imaginary' (Steinitz 80), afford plausibility to the idea that Mary intended there to be an eventual external audience for her diaries and adapted them accordingly, inscribing her artistic and authorial agency as well as her dynamic character and rebellious spirit. Lynn Bloom points out that 'truly private diaries' reveal so little about their content (being largely incomprehensible to others because written for the self) that they necessarily 'exclude the reader' (Bloom 
25). Contrastingly, though written in tiny writing, Mary's highly-detailed and descriptive anecdotes are not encrypted in code like the diaries of Anne Lister, or indecipherable due to use of excessive shorthand, but rather carefully recorded and perhaps just as carefully selected for public consumption.

Mary's diaries paint an alternative, more nuanced and arguably more accurate portrait of her marriage and of herself, which undermine longstanding perceptions of the couple and patriarchal concepts of gender as well as assumptions about Victorian marriage. She publicly revered her husband and maintained a secondary place to him, yet assumed an increasingly dominant and authoritative role in their marriage and in the studio, where she transgressed feminine norms in word and action. Using her narrative of togetherness to highlight her own significant interventions and interactions with Victorian Britain's most famous and respected artist, she reveals herself to be an active and influential creative partner or 'significant other' rather than a passive and peripheral wife who unquestioningly worshipped her husband and praised everything he produced. By incorporating her artistic activities into the traditional Victorian female role of housewife, working with her husband and within their studio-house or its surrounding grounds, she found a way to reconcile her professional creative practice with her persona as 'wife of a great artist' who gradually emerged from his shadow. The recent opening of Limnersleasewith its newly-restored Watts Studios-and the publication of Mary's diaries (Greenhow 2016) will ensure the recovery and revival of her marginalised life/writing, and the reclamation of her as a remarkable writer as well as artist.

\section{Notes}

1. For the sake of clarity and to avoid confusion between figures with the same surnames, George Watts and Mary Watts will henceforth be referred to by their first names.

2. Edward Burne-Jones's painting depicts Mrs. Bluebeard of Charles Perrault's 1697 fairy tale.

3. See Mary Watts, Diary 23 November 1887: 'came home to read our Pall Mall-several interesting things in it \& account of the police in Trafalgar Square-Signor begged me not to read that nor anything political'. Mary refers to 'Bloody Sunday', London, 13 November 1887.

4. Craddock's Godalming Almanac and Directory (33); see Craddock's Godalming Directories (1910, 1911, 1913), Godalming Museum Library for information on Mary's position in the local Suffrage Society. 'Women and the Vote' ('Last Night's Meeting'), Surrey Advertiser, 29 November 1913. Copy courtesy of Sarah Sullivan 21/07/16.

5. Anna Mary Howitt gave up painting for exhibition on her marriage to Alaric Watts in 1859; Mary Severn gave up painting on her marriage to Charles Newton in 1861; and Lucy Madox Brown's artistic career was effectively curtailed by her marriage to William Rossetti in 1874 . There were some nineteenth-century women writers who reconciled marriage with creative careers, including British novelists Elizabeth Gaskell and Mary Augusta (Mrs Humphry) Ward, although they did not actively work in creative partnerships with their husbands nor overtly combine their creative work with a commitment to socio-political causes (see Cherry 33-37).

6. Mary is probably referring to the English sculptor and goldsmith Sir Alfred Gilbert, R. A. (1854-1934), whose portrait was painted by George Watts in 1896, as listed in Mary's Catalogue, Watts Gallery archives.

\section{Acknowledgements}

With thanks to Watts Gallery - Artists' Village and the University of Surrey for enabling me to conduct this research. All images and archive materials are reproduced with the kind permission of Watts Gallery - Artists' Village. 


\section{Disclosure statement}

No potential conflict of interest was reported by the author.

\section{Notes on contributor}

Lucy Ella Rose is Teaching Fellow in English Literature at the University of Surrey, where she completed her $\mathrm{PhD}$ in 2015. Her interdisciplinary $\mathrm{PhD}$ thesis, titled Women in Nineteenth-Century Creative Partnerships: the 'Significant Other', examines the role of women in artistic and literary professions and partnerships, and the rise of feminism through artistic and literary discourses. Rose has worked on the Mary Watts archive at Watts Gallery (Surrey) for the past five years, and helped transcribe Mary's diaries for publication. Her first monograph Suffragist Artists in Partnership: Gender, Word and Image is currently under contract with Edinburgh University Press.

\section{References}

Bills, Mark. "'Two Artists who are of Just the Same Mind Concerning their Ideals of Art': George Frederic Watts (1817-1904) and Mary Seton Watts (1849-1938).” In An Artists' Village: G. F. Watts and Mary Watts at Compton. Ed. Mark Bills. London: Philip Wilson Publishers Ltd. 2011. 9-23.

Bloom, Lynn Z. "II Write for Myself and Strangers': Private Diaries as Public Documents." In Inscribing the Daily: Critical Essays on Women's Diaries. Eds. Suzanne L. Bunkers and Cynthia A. Huff. Amherst: University of Massachusetts Press, 1996.

Blunt, Wilfrid. England's Michelangelo: A Biography of George Frederic Watts. London: Hamish Hamilton, 1975.

Chapman, Ronald. The Laurel and the Thorn; A Study of G. F. Watts. London: Faber and Faber Limited, 1945.

Cherry, Deborah. Painting Women: Victorian Women Artists. London: Routledge, 1993.

Delafield, Catherine. Women's Diaries as Narrative in the Nineteenth-Century Novel. Ashgate: Farnham, 2009.

Friederichs, Hulda. "An Interview with Mr. G. F. Watts, R.A.” The Young Woman: A Monthly Journal and Review 39 (1895): 73-82.

Gould, Veronica Franklin. Mary Seton Watts (1849-1938): Unsung Heroine of the Art Nouveau. London: Lund Humphries Publishers Ltd (Veronica Franklin Gould), 1998.

Lee, Hermione. Body Parts: Essays on Life-Writing. London: Pimlico, 2008.

Michie, Helena. Victorian Honeymoons: Journeys to the Conjugal. Cambridge: Cambridge University Press, 2006.

Millim, Anne-Marie. "The Victorian Diary: Between the Public and the Private." Literature Compass 7/10 (2010): 977-988. (Blackwell Publishing Ltd). Accessed 20 Apr. 2016. Doi:10. 1111/j.1741-4113.2010.00750.x

Peeters, Nic. "Pre-Raphaeladies." In The Review of the PRS (Vol. X, No. 2). Ed. Serena Trowbridge. 2002. 17-27.

Peterson, Linda H. Traditions of Victorian Women's Autobiography: The Poetics and Politics of Life Writing. Charlottesville and London: University Press of Virginia, 1999.

Rubinstein, David. "Cycling in the 1890s." Victorian Studies 21:1 (1977): 47-71. Accessed 19 Apr. 2013. http://www.jstor.org/stable/3825934.

Smith, Elise Lawton. Evelyn Pickering De Morgan and the Allegorical Body. London: Associated University Presses, 2002.

Steinitz, Rebecca. Time, Space, and Gender in the Nineteenth-Century British Diary. New York: Palgrave Macmillan, 2011.

Unwin, Melanie. "Significant Other: Art and Craft in the Career and Marriage of Mary Watts." Journal of Design History 17:3 (2004): 237-250. Accessed 13/04/2012. Doi:10.1093/jdh/17.3.237.

Watts, Mary. Diaries 1886-87, 1891, 1893, 1896, 1898, 1902, 1904, 1906-08. Watts Gallery Archives. 
Watts, Mary. The Word in the Pattern: A Key to the Symbols on the Walls of the Chapel at Compton. London: W. H. Ward \& Co. Ltd., 1905.

Watts, Mary. George Frederic Watts: The Annals of An Artist's Life [Vols. I-III]. London: Macmillan and Co. Ltd., 1912.

Watts, Mary. The Diary of Mary Watts 1887-1904. Trans Desna Greenhow, Lucy Ella Rose and Gail Naughton. Ed. Desna Greenhow. London: Lund Humphries. 2016.

Woolf, Virginia. "Professions for Women." In The Death of the Moth and Other Essays. Ed. Leonard Woolf. New York: Harcourt Brace \& Co. 1942. 235-242.

Woolf, Virginia. Selected Diaries. Ed. Anne Olivier Bell. London: Vintage. 2008. [first published under the title A Moment's Liberty: The Shorter Diary by The Hogarth Press, 1990]. 